\author{
Анжелика Н. Кирюхина ${ }^{\text {a, } @ \text { ID }}$; Ольга К. Кобзева ${ }^{\text {a }}$; Аарья В. Акельева ${ }^{\text {a }}$ \\ ${ }^{a}$ Кемеровский государственный университет, Россия, г. Кемерово \\ @oop.vo.ef@gmail.com \\ ID https://orcid.org/0000-0001-8605-1332
}

Анамиз потребности в рабочей симе на рынке труАа моногородов Кузбасса*

Поступика в реАакцию 15.03.2020. Принята к печати 22.05.2020.

\begin{abstract}
Аннотация: Состояние занятости на региональных рынках труда является реальным определяющим фактором экономического развития территории. Актуальность темы обусловлена проблемой создания рабочих мест на рынке труАа Кузбасса в городских поселениях с монопрофильной направленностью. Предмет исследования - открытые вакансии в моногородах Кемеровской области, цель - выявление областей профессиональной деятельности с наибольшим Аефицитом персонала в моногородах Кемеровской области. Проанализированы вакансии 24 моногородов региона. Использована база вакансий, размещенных на сайте Министерства труда и занятости Кузбасса. Вакансии сгруппированы в соответствии с реестром областей и видов профессиональной деятельности. ПреАставлена профессиональноквалификационная структура открытых вакансий по уровню и профилю образования. Отдельно рассмотрены моногорода со статусом территории опережающего социально-экономического развития. Проведено сравнение свободных рабочих мест в городах, имеющих данный статус, с программами их развития. Как показали результаты исследования, преАприятиям региона требуются специалисты преимущественно технического профимя со среАним профессиональным образованием, что свидетельствует о нехватке квалифицированных рабочих. В моногородах области наблюАается преобладание открытых вакансий в зАравоохранении, транспорте и промышленности. Результаты рекомендовано использовать Аля повышения эффективности работы служб занятости населения и образовательных учрежАений Кемеровской области.
\end{abstract}

Киючевые слова: вакансия, Кемеровская область, профессионально-квалификационная структура, занятость, безработица, интернет-источник, сайт поиска работы

Аля цитирования: Кирюхина А. Н., Кобзева О. К., Акельева А. В. Анализ потребности в рабочей силе на рынке труда моногородов Кузбасса / / Вестник Кемеровского государственного университета. Серия: Политические, социологические и экономические науки. 2020. Т. 5. № 3. С. 350-359. DOI: https://doi.org/10.21603/2500-3372-2020-5-3-350-359

\section{Введение}

Рынок труда как сложный распределительный механизм, обеспечивающий прикрепление работников к рабочим местам, имеет особое место в современной экономике и оказывает влияние не только на производительность и темпы роста, но и на многие Аругие показатели экономики $[1 ; 2]$. Экономический рост и повышение благосостояния в первую очереАь связаны с воспроизводством рабочей силы и тенденциями развития сферы занятости населения России и ее регионов. Анализ общероссийского рынка труАа и макроэкономических тенденций не учитывает и не отражает специфики состояния региональных рынков труаа. МежАу тем состояние занятости на региональных рынках труда является реальным определяющим фактором экономического развития региона [3, с. 17].

Важным явлением, характеризующим нестабильность в стране и имеющим циклический характер развития, выступает безработица $[4 ; 5]$. Изучение и решение проблемы незанятости мюдей явмяется важным и очень актуальным аспектом в политике мюбой страны $[6$, с. 5]. Проблема занятости в настоящее время имеет высокую значимость в связи с тем, что не кажАый специалист, обладая Ааже высокими профессиональными навыками, имеет возможность благоприятно трудоустроиться [7]. Это серьезная социальная проблема, которая возникает в рыночной экономике [8]. По Аанным Росстата, в среднем показатель безработицы по России за период с января 2019 г. по январь 2020 г. составил 4,6\%. Уровень безработицы в Кузбассе превысии среАний по России и составил $4,9 \%{ }^{1}$.

Особенно актуальны проблемы занятости в городах с монопрофимьной направленностью экономики. Высокий уровень безработицы, низкий уровень Аоходов насемения, сокращение численности населения, рост социальной напряженности - кмючевые социальные проблемы моногородов. В таких городах имеется оАно или несколько градообразующих преАприятий, и от того, насколько

\footnotetext{
* Статья написана в рамках III Всероссийской научно-практической конференции, посвященной 300-летию освоения Кузбасса, «Управление организациями в современной экономике». Специальная тема: «Цифровая трансформация управления».

${ }^{1}$ Эксперты определики уровень безработицы в Кузбассе // Газета Кемерова. 28.01.2020. Режим Аоступа: https://gazeta.a42.ru/lenta/news/72473 eksperty-opredelili-uroven-bezraboticy-v-kuzbasse/ (Аата обращения: 29.01.2020).
} 
эффективно они функционируют, насколько развита их инфраструктура и эффективно построена система местного самоуправления, зависит уровень занятости населения.

Моногорода явмяются основообразующей частью Кемеровской области, в них проживает около 70 \% насемения [9]. Статус моногорода имеют 24 муниципальных образования. Кемеровскую область вполне можно назвать регионом моногородов. Существуют отличительные признаки моногородов: эти населенные пункты создаются вблизи промышкенных преАприятий и зависимы друг от Аруга; жизнедеятельность населения моногорода зависит от градообразующего предприятия [10, с. 20]. Такая зависимость увекичивает риски ухудшения их социальноэкономического положения.

ОАной из мер поААержки со стороны Правительства РФ стало присвоение некоторым моногородам статуса территории опережающего социально-экономического развития (ТОСЭР) - экономической зоны «со Аьготными налоговыми условиями, упрощенными аАминистративными процеАурами и Аругими привикегиями», созАаваемой «ААя привлечения инвестиций, ускоренного развития экономики и укучшения жизни насемения» $[11$, c. 12]. ПодАержка на федеральном уровне помогает гороАам развиваться, она направлена на выведение моногороАов из зоны риска, на обеспечение стабильного экономического развития [12]. Статус ТОСЭР рассматривается как способ стимулирования промышиенного и инновационного развития [13, с. 128]. Из 24 моногородов Кузбасса четырем присвоен статус ТОСЭР (табл. $\left.1^{2}\right)$.

Предприятиям-резидентам, созданным в рамках программы ТОСЭР, присущ особый мьготный налоговый режим. При этом оАним из условий получения статуса предприятия-резидента явмяется создание не менее 10 рабочих мест. Это оказывает существенное влияние на экономику городов, помогает им развиваться, а безработным гражАанам - трудоустраиваться.

Поскольку в моногородах сформирована монопрофильная занятость, наиболее высокому риску несбалансированности рынка труАа подвержены именно территории монопрофильных муниципальных образований, а проблемы занятости явмяются особо актуальными и требуют тщательного научного анализа. В связи с этим целью исслеАования явмяется выявление областей профессиональной Аеятельности с наибольшим количеством вакансий в моногородах Кемеровской области и их профессиональноквалификационной структуры; предметом - открытые вакансии в моногородах Кемеровской области.

\section{Методы и материалы}

Нами были изучены интернет-источники, которые содержат информацию о вакантных рабочих местах, поскольку в настоящее время онлайн-поиск работы стал наибомее предпочтительным методом среди соискателей [14]. Использование интернет-технологий значительно упростило процессы найма и поиска работы. Тенденция повышения актуальности Интернета обуславливает необхоАимость изучения его различных инструментов (сайты, социальные сети, чат-боты и т. А.), которые помогают в труАоустройстве гражАан. Преимуществами проведения первичных исследований в интернет-среде явмяются быстрота проведения, экономичность, широта охвата (Интернет позволяет получить Аоступ к разным группам потребитемей, разной географической уАаленности) [15, с. 36].

На начальном этапе исследования были изучены наиболее попумярные интернет-источники, предоставмяющие информацию об открытых вакансиях Аля работников и работодатемей: Работа.py, HeadHunter, Интерактивный портал Министерства труда и занятости населения Кузбасса. Вакансии на перечисленных сайтах незначительно отличались Аруг от Аруга. Согласно ст. 25 закона «О занятости населения в Российской ФеАерации» ${ }^{3}$, работодатеми обязаны содействовать проведению государственной политики занятости насемения и ежемесячно преАоставмять органам службы занятости населения информацию о наличии открытых вакансий Аля размещения на сайте. Поэтому Аля более детального анализа вакансий был выбран официальный ежеАневно обновляемый источник - Интерактивный портац Министерства труда и занятости Кузбасса (ранее: Аепартамент труда и занятости Кемеровской области $)^{4}$.

Табц. 1. Города со статусом ТОСЭР

Tab. 1. TASED towns

\begin{tabular}{|l|c|l|c|c|}
\hline \multicolumn{1}{|c|}{ ГороА } & $\begin{array}{c}\text { Аата присвоения } \\
\text { статуса ТОСЭР }\end{array}$ & \multicolumn{1}{|c|}{ ГраАообразующее преАприятие } & $\begin{array}{c}\text { Численность } \\
\text { насемения }\end{array}$ & $\begin{array}{c}\text { ПмощаАь, } \\
\text { км }^{\mathbf{2}}\end{array}$ \\
\hline Анжеро-СуАженск & 19.09 .2016 & ООО «Шахтоуправление Анжерское» & 71787 & 119,2 \\
\hline Новокузнецк & 16.03 .2018 & ООО «ЕВРАЗ ЗСМК» & 552445 & 424,27 \\
\hline Юрга & 07.07 .2016 & ООО «ЮМЗ» & 81733 & 44,8 \\
\hline Прокопьевск & 03.12 .2018 & АО «СУЭК-Кузбасс» & 196406 & 227,5 \\
\hline
\end{tabular}

\footnotetext{
${ }^{2}$ Составлено по данным Инвестиционного портала Кузбасса. Режим доступа: https://keminvest.ru/sections/5c1a8d19be33195525000045 (Аата обращения: 10.05.2019).

${ }^{3}$ О занятости населения в Российской Федерации. Закон РФ от 19.04.1991 № 1032-1 (реА. от 02.12.2019) // СПС КонсультантПАюс.

${ }^{4}$ Интерактивный портам Министерства труда и занятости насемения Кузбасса. Режим доступа: http://ufz-kemerovo.ru/ (Аата обращения: 01.02.2019).
} 
Амя исследования выбраны вакансии 24 моногородов Кемеровской области. Все вакансии сгруппированы в соответствии с реестром областей и видов профессиональной деятельности ${ }^{5}$ отдельно аля кажАого города. Анализ проводился в феврале - июне 2019 г. Применены метоА теоретического анализа, позволяющий выделить и рассмотреть отдельные стороны, свойства явлений, признаки, особенности исследуемых объектов; анализ информационных Аанных интернет-источников; статистические методы; графические и табличные методы преАставления данных.

\section{Результаты}

Экономика большинства городов Кемеровской области базируется на работе промышиенных предприятий. К приоритетным отраслям развития региона относятся добыча полезных ископаемых (угля и железной руды), метамлургическое производство, машиностроение, химическое производство, развитие транспортной инфраструктуры, сельское хозяйство и производство проАуктов питания [16, с. 126].

Наибольшую потребность в работниках испытывают зАравоохранение $(20,9 \%)$, транспорт $(20,1 \%)$ и промышменность $(18,7 \%)$. Высокий удельный вес также занимают добыча и переработка угля, руА и Аругих полезных ископаемых (14,9\%) и сервис, оказание услуг населению $(11,2 \%)$. Меньшие Аоли приходятся на сферы строительства и ЖКХ (6 \%), безопасности (3,7 \%), образования и науки $(3,7 \%)$.

В зАравоохранении преобладают вакансии меАсестер и высококвалифицированных врачей в государственных медучреждениях. На транспорте больше всего требуются водители в государственные пассажирские автотранспортные преАприятия (ГПАТП), в промышменности, Аобыче и переработке угля - машинисты, слесари-ремонтники, сварщики, горнорабочие, эмектрослесари подземные.

Анализ банка вакансий в разрезе моногородов показал преобладание вакансий от общего их числа в следующих областях профессиональной Аеятельности: промышменность - в Салаире (77,8 \%), Топках (37\%), Мысках $(21,2 \%)$, Краснобродском (23\%), Тайге $(26 \%)$; добыча, переработка угля, руА и Аругих полезных ископаемых - в Осинниках (50\%), Киселевске (18,1\%), АенискеКузнецком (28,2 \%), Полысаеве (54,5 \%), Межауреченске $(30,7 \%)$; транспорт - в Белове $(21,9 \%)$, Белогорске $(25,6 \%)$, Новокузнецке $(19,5 \%)$, Тайге $(26 \%)$; эмектроэнергетика - в Калтане $(33,1 \%)$; обеспечение безопасности - в Мариинске $(32,6 \%)$; сервис, оказание ускуг насемению - в Шерегеше (21,3\%).

Высокий Удельный вес вакансий промышленности вызван, прежде всего, наличием развитого промышленного сектора в моногородах и созданием там рабочих мест в рамках приоритетного проекта «Комплексное развитие моногородов». Анализ профессионально-квалификационной структуры исследуемых вакансий в моногородах позволяет ранжировать потребность в работниках по уровню и профилю образования (рис.) [17].

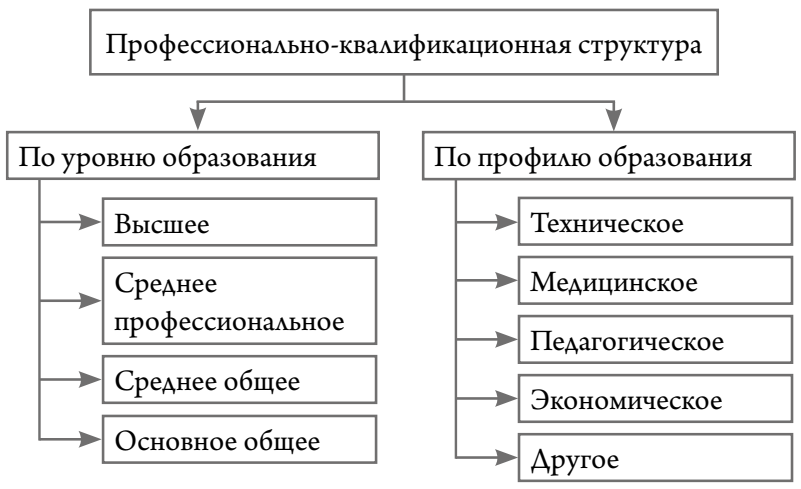

Рис. Профессионально-квалификационная структура

Fig. Vocational qualification structure

Образование как интемлектуальный ресурс явмяется Авижущей силой современного общества. Оно созАает потенциа развития населения и определяет пути его продвижения впереА [18]. Аанные свидетельствуют о наибольшей востребованности специалистов со среАним профессиональным образованием, т. к. его удельный вес составцяет $51,31 \%$, на втором месте специалисты с высшим образованием - 23,23\%, Аалее работники со средним общим образованием (11 классов) - 17,24\%. Наименьшее количество открытых вакансий Аля работников с основным общим образованием (9 классов) - 8,22 \%.

В моногородах Кемеровской области преобладает спрос на профессии технического профимя - 59,02\%. Высокий спрос на специалистов с меАицинским образованием (17,09\%). Наименьшая домя вакансий приходится на педагогических работников $(5,15 \%)$ и на работников с экономическим образованием (1,11\%). Специалисты технического профильного образования в основном требуются Амя обслуживания электроэнергетики, транспортной и железнодорожной инфраструктуры.

Аенежной компенсацией за труА в зависимости от квамификации работника явмяется заработная плата. В большинстве случаев работодатели предлагают заработную плату в диапазоне от 14 тыс. руб. до 25 тыс. руб. (удельный вес вакансий - 59,69\%). Вакансии с заработной платой 25-36 тыс. руб. составмяют 20,42 \%. УАемьный вес вакансий с заработной платой до 14 тыс. руб. - 11,73\%, в основном это вакансии на неполный рабочий день. Аалее идут вакансии с зарплатой 36-47 тыс. руб. (5,61 \%). Наименьшая Аомя рабочих мест с заработной платой свыше 47 тыс. руб. (2,55 \%) - это вакансии на руководящие Аолжности с высокой степенью ответственности.

\footnotetext{
5 Реестр областей и видов профессионамьной деятельности. Режим доступа: https://profstandart.rosmintrud.ru/obshchiy-informatsionnyy-blok/ natsionalnyy-reestr-professionalnykh-standartov/reestr-oblastey-i-vidov-professionalnoy-deyatelnosti/ (Аата обращения: 01.02.2019).
} 
Как уже отмечалось, особое место в перечне моногородов занимают муниципальные образования со статусом ТОСЭР. Рассмотрим основные позиции программ развития четырех кузбасских городов ТОСЭР и состояние открытых в них вакансий.

\section{Анжеро-Судженск}

В Анжеро-Судженске на 2020-2024 гг. запланированы слеАующие инвестиции в промышленность:

1) реализация проекта по производству широкоформатной фанеры;

2) строительство мясоперерабатывающего комбината;

3) разработка нового месторождения кварцитов.

Пианируется возобновление функционирования Анжерского фанерного комбината, который находился на стадии банкротства на конкурсном производстве. В настоящее время завод выставлен на торги, ведутся работы по поиску инвесторов.

С момента присвоения городу статуса ТОСЭР в число его резидентов вошел ряд преАприятий ${ }^{6}$. Аеятельностью ООО « АесПромМакс» и ООО «АверсИес-Инвест» явцяется распиловка и строгание Аревесины. ООО «Анжеро-СуАженский мелькомбинат» специализируется на производстве продуктов мукомольной и крупяной промышленности, ООО «Морион» мекарственных препаратов и материалов, применяемых в медицинских целях, ООО «Мир» - прочей неметалмической минеральной продукции, не включенной в остальные группировки.

Из имеющихся вакансий больше всего приходится на промышиенность - 33,5 \%, строительство и ЖКХ $23,5 \%$, сельское хозяйство, месное хозяйство, охоту - $17 \%$. Низкие значения имеют следующие отрасли: транспорт $7 \%$, эмектроэнергетика - $5 \%$, сервис, оказание ускуг насемению и зАравоохранение - по $4 \%$, образование и административно-управленческая, офисная деятельность - по $2 \%$, связь, информационные и коммуникационные технологии и финансы и экономика - по $1 \%$.

СреАи преАприятий города вакансии распределились следующим образом. Аоля открытых вакансий на преАприятиях, созданных в рамках программы ТОСЭР, составмяет 44,87\%: ООО « АесПромМакс» $(33,33 \%)$ и ООО «Аверс-Иес-Инвест $\gg(11,54 \%)$.

Уже существующие промышиенные преАприятия преАлагают 55,13\% вакансий: ООО «Анжеромаш» $(33,33 \%)$, ООО «Молочная перерабатывающая компания» (2,56\%), ООО «Анжерские колбасы» $(1,28 \%)$, ООО «Сибирский колос» $(12,82 \%)$, ООО « рерабатывающая компания» $(5,14 \%)$. Градообразующее преАприятие «Шахтоуправление Анжерское» миквидировано6 ноября 2018 г., что объясняет отсутствие вакансий в отрасли добычи и переработки угля. Высокий удельный вес вакансий в этих областях обусловмен стратегией социально-экономического развития города, направленной на строительство жилья, развитие инфраструктуры, строительство нефтеперерабатывающего и месопромышленного комплекса.

Амя промышкенности наиболее востребованы работники следующих профессий: инженер-технолог (9 вакансий), инженер-конструктор (6 вакансий), экектрослесарь (слесарь) и дежурный по ремонту оборудования (8 вакансий).

\section{Новокузнецк}

Согласно инвестиционному паспорту города, оАной из самых перспективных инвестиционных ниш Новокузнецка считается промышиенность, а именно: производство строительных материалов, химическое, пищевое, текстильное и швейное производства.

Стратегия социально-экономического развития Новокузнецкого городского округа до 2035 г. направлена на развитие транспортной, коммуникационной и инженерной инфраструктур, совершенствование экологической системы города. Развитие транспортной инфраструктуры предполагает:

1) реконструкцию Абагуровского моста через р. Томь;

2) строительство моста через р. Кондому;

3) ремонт 18 участков автомобильных дорог города;

4) запуск новых видов городского транспорта (беспимотный транспорт, развитие водного и авиатранспорта) и т. А.

В рамках реализации стратегии социально-экономического развития планируется реализация проекта по произвоАству синтетических газов ООО «ЭР АикиА Кузбасс», а также модернизация и развитие уже существующих производственных преАприятий. В первую очередь это касается метаммургических производств, т. к. требования к экологической безопасности пересматриваются и выхоАят на новый уровень - становятся более жесткими. К таким преАприятиям относятся АО «ЕВРАЗ ЗСМК», АО «РУСАЦ Новокузнецк», АО «Органика», ПАО «Межрегиональная распределительная сетевая компания Сибири» - «Кузбассэнерго-РЭС», ООО «Сибирская горно-метамургическая компания», ООО «Антрацит», ООО «Горный инструмент».

В настоящее время в г. Новокузнецке в рамках ТОСЭР создано 23 преАприятия, более половины из них - промышиенные. В таблице 2 преАставлены промышиенные преАприятия - резиденты ТОСЭР г. Новокузнецка ${ }^{7}$.

\footnotetext{
${ }^{6}$ Анжеро-Судженск // Инвестиционный портал Кузбасса. Режим доступа: https://keminvest.ru/ru/pages/589bdc3c77686f15082d0000 (Аата обращения: 10.05.2019).

${ }^{7}$ Новокузнецк // Инвестиционный портах Кузбасса. Режим доступа: https://keminvest.ru/ru/pages/5c48370ebe33191997002c97 (Аата обращения: 10.05.2019).
} 
Табл. 2. ПреАприятия - резиденты ТОСЭР Новокузнецка Tab. 2. Resident enterprises of Novokuznetsk TASED

\begin{tabular}{|c|c|}
\hline ПреАприятие & Описание Аеятельности \\
\hline ООО «РудтехПродакшн» & \multirow{3}{*}{$\begin{array}{l}\text { Производство машин } \\
\text { и оборудования Амя Аобы- } \\
\text { чи полезных ископаемых } \\
\text { и строительства }\end{array}$} \\
\hline $\begin{array}{l}\text { ООО «НПО Антрацит- } \\
\text { Машиностроение» }\end{array}$ & \\
\hline ООО «ТехноТРОН $»$ & \\
\hline $\begin{array}{l}\text { ООО «Сибирский центр } \\
\text { стекма» }\end{array}$ & \multirow[t]{3}{*}{$\begin{array}{l}\text { Формирование и обработка } \\
\text { мистового стекла }\end{array}$} \\
\hline $\begin{array}{l}\text { ООО «Новокузнецкий } \\
\text { стеклоперерабатывающий } \\
\text { завоА» }\end{array}$ & \\
\hline $\begin{array}{l}\text { ООО «СибГАасс- } \\
\text { Новокузнецк» }\end{array}$ & \\
\hline $\begin{array}{l}\text { OОО } \\
\text { «ПромРаАиатор-НК» }\end{array}$ & \multirow{2}{*}{$\begin{array}{l}\text { Производство радиаторов } \\
\text { и котмов центрацьного } \\
\text { отопления }\end{array}$} \\
\hline ООО «Теплотрон» & \\
\hline АО «Энергия ХомАинг» & $\begin{array}{l}\text { Производство экектриче- } \\
\text { ского оборудования }\end{array}$ \\
\hline OОО «ГРАНА $»$ & $\begin{array}{l}\text { Производство минерамь- } \\
\text { ных тепло- и звукоизо- } \\
\text { мяционных материалов } \\
\text { и изделий }\end{array}$ \\
\hline $\begin{array}{l}\text { ООО «Социальный } \\
\text { партнер» }\end{array}$ & $\begin{array}{l}\text { Обработка отходов } \\
\text { резины }\end{array}$ \\
\hline $\begin{array}{l}\text { ООО «Сибирский Марле- } \\
\text { вый Комбинат» }\end{array}$ & $\begin{array}{l}\text { Производство мекарствен- } \\
\text { ных препаратов и мате- } \\
\text { риалов, применяемых } \\
\text { в медицинских цемях }\end{array}$ \\
\hline ООО «СпецТехЗавоА» & $\begin{array}{l}\text { Обработка метаммов } \\
\text { и нанесение покрытий } \\
\text { на метаммы }\end{array}$ \\
\hline ООО «Монолит » & $\begin{array}{l}\text { Производство товарного } \\
\text { бетона }\end{array}$ \\
\hline $\begin{array}{l}\text { ООО «Сервисная уголь- } \\
\text { ная компания» }\end{array}$ & $\begin{array}{l}\text { Производство электри- } \\
\text { ческой распределитель- } \\
\text { ной и регулирующей } \\
\text { аппаратуры } \\
\end{array}$ \\
\hline ООО «Элисса» & $\begin{array}{l}\text { Производство прочих } \\
\text { изАелий из гипса, бетона } \\
\text { или цемента }\end{array}$ \\
\hline $\begin{array}{l}\text { ООО «ЗавоА инновацион- } \\
\text { ного машиностроения» }\end{array}$ & $\begin{array}{l}\text { Производство } \\
\text { и ремонт инновацион- } \\
\text { ного горно-шахтного } \\
\text { оборудования }\end{array}$ \\
\hline $\begin{array}{l}\text { ООО «Фабрика сладкого } \\
\text { Аекора» }\end{array}$ & $\begin{array}{l}\text { Производство жировых } \\
\text { и сахаристых масс, сухих } \\
\text { функциональных смесей } \\
\text { ААя преАприятий конди- } \\
\text { терской промышленности }\end{array}$ \\
\hline
\end{tabular}

Наибольшая Аоля вакансий Новокузнецка прихоАится на промышиенность и транспорт - по 19,5\% и зАравоохранение - $12,5 \%$. Новокузнецк - один из железнодорожных узмов Кузбасса, поэтому требуются специалисты на железнодорожный транспорт. Высокий удельный вес зАравоохранения вызван спросом на медсестер (284 вакансии). Сфера строительства и ЖКХ предоставляет 12,3 \% вакансий, сервиса и оказания услуг населению $9 \%$, обеспечения безопасности - $7 \%$, эмектроэнергетики - $5 \%$, образования, аАминистративно-управленческой и офисной деятельности, финансов и экономики - по $2 \%$. Градообразующими в Новокузнецке являются метаммургические преАприятия, оАнако Аоля вакансий в области метамлургического производства занимает мишь 9,2\%, что говорит о занятости рабочих мест.

Аоля вакансий преАприятий, созданных в рамках программы ТОСЭР, составмяет 22,63 \%: АО «Энергия ХомАинг» $(22,35 \%)$ и ООО «Теплотрон $\gg(0,28 \%)$.Уже существующие промышленные преАприятия - 77,37 \%: ПАО «Межрегиональная распределительная сетевая компания Сибири»-«Кузбассэнерго-РЭС $(4,47 \%)$, АО «Кузнецкие ферроспиавы» $(27,93 \%)$, АО «Органика» $(13,41 \%)$, АО «РУСАЛ Новокузнецк» $(6,42 \%)$, ООО «Горный инструмент» $(5,87 \%)$, ООО «СибПромМаш» $(1,68 \%)$, АО «Завод Универсал» $(10,89 \%)$, АО «ЕВРАЗ ЗСМК» $(4,75 \%)$, ООО «Завод строительных изделий» $(1,96 \%)$. Аоля открытых вакансий преАприятий, созАанных в рамках программы ТОСЭР, в 3 раза ниже, чем доля уже существующих промышленных преАприятий.

\section{Юрга}

Основной заАачей инвестиционного и промышленного развития Юрги явмяется разработка действенных механизмов по привлечению инвестиций в экономику гороАа. За 2016-2018 гг. в рамках программы ТОСЭР зарегистрировано 4 предприятия - резидента г. Юрги ${ }^{8}$. Это ООО «Объединенная Аеревообрабатывающая Торговопромышленная компания», занимающаяся производством фанеры, Аеревянных фанерованных панелей и аналогичных слоистых материалов, Аревесных плит из Аревесины и Аругих оАревесневших материалов; ООО «Текстильная фабрика "Сибирь"», производящая трикотажное и вязаное полотно, спецодежАу и т.А.; ООО «Юргинская фабрика нетканых материалов», специализирующаяся на производстве нетканых текстильных материалов и изделий из них, кроме одежАы; НАО «Томский машиностроительный завоА», Аеятельностью которого явмяется произвоАство автотранспортных среАств.

Открытые вакансии г. Юрги преоблаАают в областях зАравоохранения - 27,5 \%, промышиенности - 24,3 \%, сервиса $-8,2 \%$. Самыми востребованными профессиями явцяются меАсестра (30 вакансий) и врач (66 вакансий).

\footnotetext{
${ }^{8}$ Юрга // Инвестиционный портам Кузбасса. Режим Аоступа: https://keminvest.ru/ru/pages/595f00a0be33190c3900000d (Аата обращения: 10.05.2019).
} 
Менее востребованы работники области обеспечения безопасности $-8 \%$, электроэнергетики - $7 \%$, метамургического производства, финансов и экономики - по $6 \%$, образования $-5 \%$, строительства и ЖКХ и транспорта - по $4 \%$.

ООО «Юргинская фабрика нетканых материалов», созданная в рамках программы ТОСЭР, преАлагает $1,82 \%$ рабочих мест. Уже Аействующие промышленные предприятия Аают 98,18 \% вакансий: ООО «Юргинский машзавоА» $(54,92 \%)$, ОАО «Юргинский гормомзавоА» $(2,46 \%)$, ООО «Спецпром» $(4,10 \%)$, ООО «Агротех» $(3,28 \%)$, «Юргинский ферросплавный завоА» (филиа АО «Кузнецкие ферросплавы») (34,43\%).

Таким образом, практически все вакансии представлены уже Аействующими преАприятиями, в основном градообразующим преАприятием - «Юргинским машзаводом». Аоля вакансий на преАприятиях - резидентах ТОСЭР незначительна, т. к. эти преАприятия еще только начинают свою Аеятельность и не вышии на полную мощность. Например, НАО «Томский машиностроительный завоА» стал резидентом Юрги в Аекабре 2018 г., но на полную мощность планирует выйти только к 2024 г. ПреАприятие будет выпускать экскаваторы Амфибия Амя работы в нефтеперерабатывающей и добывающей отрасли.

\section{Прокопьевск}

В цемях развития промышленного комплекса Прокопьевска и созАания условий Аля устойчивого роста экономического потенциала на территории города планируется реализовать различные инвестиционные проекты, проАукция которых будет отличаться высокой конкурентоспособностью, удовлетворять рыночные потребности, способствовать импортозамещению. Проекты запланированы к осуществлению на 2017-2024 гг. В настоящее время в Прокопьевске в рамках программы ТОСЭР создано 3 преАприятия-резидента: ООО «Трансинтермаш» (производство подъемно-транспортного оборудования), ООО «Прокопьевский митейно-механический завоА» (Аитье стали) и ООО «Аего» (произвоАство изАелий из бетона Аля использования в строительстве) ${ }^{9}$.

Градообразующее предприятие Прокопьевска АО «СУЭК-Кузбасс». Вакансии в области добычи угля составцяют Аишь $3 \%$, что говорит о занятости рабочих мест. Больше всего вакансий преАставлено в зАравоохранении $-41 \%$, транспорте $-21 \%$ и промышиенности $-12 \%$. Самыми востребованными явмяются профессии врача (188 вакансий) и медсестры (208 вакансий). Преимущественно требуются водители пассажирского транспорта и мегковых автомобилей (142 вакансии), по 1/3 от вакансий требуется в Прокопьевское ГПАТП Кемеровской области и Управление вневедомственной охраны войск национальной гвардии России по Кемеровской области. Невысокий процент вакансий размещен работодатемями сфер строительства и ЖКХ - 6 \%, сервиса, оказания услуг насемению - $5 \%$, образования и электроэнергетики по $4 \%$. По $1 \%$ рабочих мест имеется в области финансов и экономики, социамьного обскуживания, обеспечения безопасности и юриспруденции.

Вакансии промышкенных предприятий Прокопьевска полностью преАставлены уже Аействующими промышленными преАприятиями: ООО «ОМТ» $(37,78 \%)$, ООО «Метамло-Механический ЗавоА» (20\%), ООО «Электропром» $(17,78 \%)$, ООО «ТриТэкс» $(11,11 \%)$, ООО «Горэкс-Светотехника» $(6,67 \%)$, ООО «Инструмент» $(3,33 \%)$, ООО «Оливия» $(3,33 \%)$. Спрос на специалистов у преАприятий, созданных в рамках программы ТОСЭР, отсутствует, т.к. проекты резидентов находятся на стадии осуществления.

Обобщенные результаты сравнения вакантных рабочих мест на преАприятиях, созАанных в рамках программы ТОСЭР, и уже Аействующих преАприятиях привеАены в таблице 3.

Табл. 3. Сравнение вакансий Аействующих преАприятий, \% Tab. 3. Vacancies vs. residents of TASED, \%

\begin{tabular}{|c|c|c|c|c|}
\hline $\begin{array}{c}\text { УАемьный вес } \\
\text { вакансий } \\
\text { промышкенных } \\
\text { преАприятий }\end{array}$ & 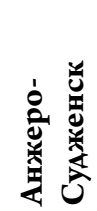 & 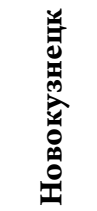 & ڤే & 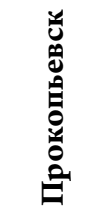 \\
\hline $\begin{array}{l}\text { Аействующие } \\
\text { преАприятия }\end{array}$ & 55,13 & 77,37 & 98,18 & 100,00 \\
\hline $\begin{array}{l}\text { ПреАприятия - } \\
\text { резиденты ТОСЭР }\end{array}$ & 44,87 & 22,63 & 1,82 & - \\
\hline
\end{tabular}

ПреАприятия, созАанные в рамках программы ТОСЭР, размещают меньшее число вакансий, чем действующие промышленные преАприятия. Это можно объяснить тем, что некоторые преАприятия - резиденты ТОСЭР еще находятся на стадии строительства и не осуществляют поАбор сотруАников. Реализация программы поААержки моногородов позволит создать дополнительные рабочие места.

\section{Закмючение}

Наибольший дефицит персонама в моногородах Кемеровской области испытывает зАравоохранение, что совпаАает с официальными статистическими данными: Кемеровская область находится в списке регионов с дефицитом обеспеченности врачами (показатель 34,4 на 10 тыс. человек населения), тогАа как обеспеченность врачами

\footnotetext{
9 Прокопьевск // Инвестиционный портах Кузбасса. Режим доступа: https://keminvest.ru/ru/pages/5c496002be3319199d00368e (дата обращения: 10.05.2019).
} 
по России в 2018 г. составила 37,4 на 10 тыс. чемовек населения ${ }^{10}$. Это обусловлено низкой заработной платой в зАравоохранении (преАложение заработной платы на вакансию медсестры в среднем составмяет 14664 руб.), а также нежеланием молодых специалистов распредемяться в малые города. Фактором наличия большого количества вакансий врачей и медсестер можно назвать высокий коэффициент совместительства (в Новокузнецке он составмяет 2,27). Зачастую участковые-терапевты и фельдшеры совмещают Аолжности узких специалистов. В России врачи всех специализаций работают более чем на одну ставку (от 1,25 ставки), в среднем на 1,45 ставки ${ }^{11}$.

Второе место по числу открытых вакансий занимает сфера транспорта, где преобладают вакансии водителей в ГПАТП, водитемей большегрузных автомобимей и железноАорожного транспорта. КаАровый Аефицит в этой области профессиональной деятельности обусловмен низкой заработной платой и тяжелыми условиями труда. Водителям ГПАТП преАлагают заработную плату в диапазоне 15-25 тыс. руб. Проблемам дефицита квалифицированных каАров транспортной отрасли, повышения престижа рабочих специальностей, создания механизма социальной защиты работников транспорта и смежных отраслей была посвящена VI Международная конференция «КаАровая политика», состоявшаяся в конце 2019 г. в Санкт-Петербурге. В ее работе приняли участие статс-секретарь заместитель министра транспорта РФ Сергей Аристов, преАставители Совета Федерации РФ, Государственной думы РФ, органов федеральной и региональной власти ${ }^{12}$.

Открытые вакансии в промышиенности отражают региональную специфику преАприятий моногороАов Кузбасса - Аобыча, переработка угля, руд и Аругих полезных ископаемых. Отсутствие вакансий на градообразующих преАприятиях большинства моногородов свидетельствует о занятости рабочих мест. Некоторые преАприятия уже киквидированы или находятся на стаАии банкротства. В результате реализации программы ПоААерЖКИ моНоГороАОв были СозАаны АоПолнительные рабочие места, но доля их вакансий невелика.

Согласно исследованию профессионально-квалификационной структуры вакансий, предприятиям требуются специалисты со среАним профессиональным образованием (51\% вакансий) с техническим профилем (59\% вакансий). От работников требуется высокая квамификация, специальные знания, умения и навыки, что свидетельствует о нехватке квалифицированных рабочих. Среди исследуемых вакансий были выбраны те, в которых промышленные предприятия испытывают наибольшую потребность. Составцен перечень топ-30 вакансий в промышленности:

1) битумщик;

2) вальцовщик;

3) взрывник;

4) газорезчик;

5) горномонтажник подземный;

6) горнорабочий очистного забоя;

7) горнорабочий подземный;

8) изготовитель блоков и панемей из кирпича;

9) инженер по бурению;

10) инженер-технолог;

11) комплектовщик панемей;

12) машинист буровой установки;

13) машинист горных выемочных машин;

14) машинист (кочегар) котельной;

15) машинист крана;

16) машинист насосных установок;

17) машинист установок обогащения и брикетирования;

18) обвамьщик;

19) проходчик;

20) слесарь по сборке метамлоконструкций;

21) слесарь-ремонтник промышиенного оборудования;

22) слесарь-ремонтник;

23) слесарь механосборочных работ;

24) станочник деревообрабатывающих станков;

25) токарь;

26) формовщик изделий, конструкций и строительных материалов;

27) фрезеровщик;

28) экектрогазосварщик;

29) эмектросварщик ручной сварки;

30) эмектрослесарь подземный.

Моногорода явмяются индикатором проблем современной российской экономики, показывая каАровый голоА в сфере зАравоохранения и транспорта, монопрофильную занятость населения. Основная доля вакансий промышиенных преАприятий приходится на профессии, связанные с тяжелым физическим трудом, вреАными или опасными условиями производства. В сложившейся ситуации преАприятиям моногородов по-прежнему требуются государственные меры поААержки Аля модернизации производства и решения каАровых проблем.

\footnotetext{
${ }^{10}$ Обеспеченность врачами (всего) в 2018 году // Национальный медицинский исследовательский центр терапии и профикактической медицины. Режим доступа: https://org.gnicpm.ru/obespechennost-vrachami-vsego-v-2018-godu (Аата обращения: 01.03.2020).

${ }^{11}$ Результаты исследования зарплаты врачей государственных медучреждений России // Врачи РФ. 01.12.2017. Режим доступа: https://vrachirf.ru/ company-announce-single/40047 (Аата обращения: 14.03.2020).

${ }^{12}$ Кадровый дефицит // Транспорт России. 31.01.2014. Режим доступа: http://transportrussia.ru/item/2004-kadrovyj-defitsit.html (Аата обращения: 14.03.2020).
} 
DOI: $10.21603 / 2500-3372-2020-5-3-350-359$

\section{Митература}

1. Азиева Р.Х. Теоретический анализ рынка труда: сущность и особенности // Sciences of Europe. 2018. № 29-1. С. 21-23.

2. Губарь О. В. Ринок праці України: реалії, проблеми і перспективи розвитку // International Journal of Innovative Technologies in Economy. 2018. T. 1. № 5. С. 36-39. DOI: 10.31435/rsglobal_ijite/01062018/5657

3. Орцханова М. А., Полонкоева Ф. Я., Китиева М. И. Современный рынок труда России: анализ и особенности развития // Colloquium-journal. 2019. № 3-7. С. 17-19.

4. Чупанова Х. А. Причины безработицы на современном рынке труда и пути ее преодоления // Вестник РМАТ. 2018. № 4. C. 42-44.

5. Žofčinová V., Hrabovská Z. Problems of unemployment through the employment policy in the labour market: the case of the Slovak Republic and the Czech Republic / / Вопросы государственного и муниципального управления. 2019 . № 5. C. 103-119. DOI: 10.17323/1999-5431-2019-0-5-103-119

6. Алмахверанов Э. И. Проблема безработицы // Colloquium-journal. 2019. № 18-6. C. 5-6. DOI: 10.24411/2520-6990-2019-10602

7. Сардарян А. Р., Петроченко А. А. Современное состояние и проблемы рынка труда в странах ЕАЭС // Изв. Сарат. ун-та. Нов. сер. Сер. Экономика. Управление. Право. 2018. Т. 18. № 1. С. 19-27. DOI: 10.18500/1994-2540-2018-18-1-19-27

8. Хомидов К. К. Socioeconomic characteristics of employment in Uzbekistan // Инновационная наука. 2019. № 7-8. С. 64-66.

9. Аысковская Н. С., Кирюхина А. Н. Тенденции развития моногородов на примере Кемеровской области // Пищевые инновации в биотехнологии: сб. тез. VI МежАунар. науч. конф. студентов, аспирантов и молодых ученых (Кемерово, 16 мая 2018 г.) Кемерово, 2018. С. 344-345.

10. Пятшева Е. Н. Особенности функционирования моногородов России // Вестник РГГУ. Серия «Экономика. Управление. Право». 2019. № 2. С. 18-34. DOI: 10.28995/2073-6304-2019-2-18-34

11. Уиицкая Н. Ю., Акимова М. С., Кокорева Т. П. Территория опережающего социально-экономического развития как фактор развития территории и привлекательности дмя резидента // Стратегии бизнеса. 2017. № 10. С. $12-16$.

12. Макарова Е. А., Кирюхина А. Н. Инвестиционный потенциал туристской привлекательности Шерегеша // Пищевые инновации в биотехнологии: сб. тез. VI МежАунар. науч. конф. студентов, аспирантов и молодых ученых. (Кемерово, 16 мая 2018 г.) Кемерово, 2018. С. 346-347.

13. Иванова О. П., Антонов Г. А. ТОСЭР в моногородах // ЭКО. 2017. № 3. С. 120-133.

14. Faberman R. J., Kudlyak M. What does online job search tell us about the labor market? // Economic Perspectives. 2016. № 1. P. $1-15$.

15. Зеркалий Н. Г. Перспективные области проведения первичных исследований потребителей в интернет-среде // Вестник Сибирского института бизнеса и информационных технологий. 2016. № 3. С. 36-40.

16. Серебряков Е. В., Пьянкова $\Lambda$. А. Аисбаланс межАу спросом и преАложением рабочей силы в Кемеровской области в 2018 году // Симвом науки. 2019. № 1. С. 125-127.

17. Нанавян А. М. Структура населения по уровню образования и насыщенность отраслей экономики каАрами // Экономическая наука современной России. 2016. № 2. С. 68-77.

18. Kasradze T., Zarnadze N. Enhancing workforce competitiveness through improving quality of education an indispensable means for overcoming poverty // International Journal of Innovative Technologies in Economy. 2018. Vol. 1. № 5. P. 19-21. DOI: 10.31435/rsglobal_ijite/01062018/5654 


\title{
Labor Demand on the Labor Market of Single-Industry Towns in Kuzbass*
}

\author{
Anzhelika N. Kiryukhina ${ }^{\text {a, } @ \text {, ID }}$; Olga K. Kobzeva ${ }^{a}$; Daria V. Akeleva ${ }^{\text {a }}$ \\ ${ }^{a}$ Kemerovo State University, Russia, Kemerovo \\ @oop.vo.ef@gmail.com \\ ID https://orcid.org/0000-0001-8605-1332
}

Received 15.03.2020. Accepted 22.05.2020.

\begin{abstract}
The state of employment on regional labor markets determines the economic development of the region. The present research owes its relevance to the problem of creating jobs on the Kuzbass labor market. The study involved data on vacancies offered in 24 local single-industry towns and posted on the website of the Department of Labor and Employment of the Kemerovo Region. The vacancies were grouped according to the register of spheres and types of professional activity. The professional qualification structure of the open vacancies was classified by the level and profile of education. A separate study was conducted for single-industry towns that possess the status of the territory of advanced social and economic development. The authors compared the open vacancies in these towns with the corresponding municipal development programs. The research objective was to identify areas of professional activity with the greatest shortage of personnel in Kuzbass single-industry towns. Enterprises in the region appeared understaffed with technical specialists with secondary vocational education. Most open vacancies were in the spheres of healthcare, transport, and industry. The study revealed a need to increase the prestige of qualified workers. The results can improve the efficiency of the employment service and educational institutions.
\end{abstract}

Keywords: vacancies, Kemerovo region, vocational qualification structure, employment, unemployment, Internet sources, job search sites

For citation: Kirukhina A. N., Kobzeva O. K., Akeleva D. V. Labor Demand on the Labor Market of Single-Industry Towns in Kuzbass. Vestnik Kemerovskogo gosudarstvennogo universiteta. Seriia: Politicheskie, sotsiologicheskie i ekonomicheskie nauki, 2020, 5(3): 350-359. (In Russ.) DOI: https://doi.org/10.21603/2500-3372-2020-5-3-350-359

\section{References}

1. Azieva R. H. Theoretical analysis of the labor market: the essence and features. Sciences of Europe, 2018, (29-1): 21-23. (In Russ.)

2. Gubar O. V. The labor market of Ukraine: realities, problems, and prospects of development. International Journal of Innovative Technologies in Economy, 2018, 1(5): 36-39. (In Ukr.) DOI: 10.31435/rsglobal_ijite/01062018/5657

3. Orskhanova M. A., Polonkoeva F. Ya., Kitieva M. I. Modern labor market in Russia: analysis and characteristics of development. Colloquium-journal, 2019, (3-7): 17-19. (In Russ.)

4. Chupanova Kh. A. Reasons for unemployment on the job market today and ways out. Vestnik RMAT, 2018, (4): 42-44. (In Russ.)

5. Žofčinová V., Hrabovská Z. Problems of unemployment through the employment policy in the labour market: the case of the Slovak Republic and the Czech Republic. Voprosy gosudarstvennogo i munitsipalnogo upravleniia, 2019, (5): 103119. DOI: $10.17323 / 1999-5431-2019-0-5-103-119$

6. Allakhveranov E. I. The problem of unemployment. Colloquium-journal, 2019, (18-6): 5-6. (In Russ.) DOI: 10.24411/2520-6990-2019-10602

7. Sardaryan A. R., Petrochenko A. A. The current state and problems of the labor market in the EAEC countries. Izv. Saratov Univ. (N. S.), Ser. Economics. Management. Law, 2018, 18(1): 19-27. (In Russ.) DOI: 10.18500/1994-2540-2018-18-1-19-27

8. Khomidov K. K. Socioeconomic characteristics of employment in Uzbekistan. Innovatsionnaia nauka, 2019, (7-8): 64-66.

9. Lyskovskaia N. S., Kiryukhina A. N. Tendencies of development of single-industry towns based on the case of the Kemerovo region. Food innovations in biotechnology: Proc. VI Intern. Sci. Conf. students, postgraduates, and young scientists, Kemerovo, May 16, 2018. Kemerovo, 2018, 344-345. (In Russ.)

10. Pyatsheva E. N. The functioning features of single-industry towns in Russia. RGGU/RSUH Bulletin. "Economics. Management. Law" Series, 2019, (2): 18-34. (In Russ.) DOI: 10.28995/2073-6304-2019-2-18-34

11. Ulitskaya N. Yu., Akimova M. S., Kokoreva T. P. The territory of advancing socio-economic development as a factor of development of the territory and attractions for the resident. Strategii biznesa, 2017, (10): 12-16. (In Russ.)

\footnotetext{
* The article was written for the III All-Russian Scientific and Practical Conference "Management of organizations in the modern economy" dedicated to the 300th Anniversary of Kuzbass Exploration, topic: Digital Management Transformation.
} 
DOI: $10.21603 / 2500-3372-2020-5-3-350-359$

12. Makarova E. A., Kiryukhina A. N. Investment potential of tourist attractions in Sheregesh. Food innovations in biotechnology: Proc. VI Intern. Sci. Conf. students, postgraduates, and young scientists, Kemerovo, May 16, 2018. Kemerovo, 2018, 346347. (In Russ.)

13. Ivanova O. P., Antonov G. D. Priority social and economic development areas in factory-based towns. ECO, 2017, (3): 120-133. (In Russ.)

14. Faberman R. J., Kudlyak M. What does online job search tell us about the labor market? Economic Perspectives, 2016, (1): 1-15.

15. Zerkaliy N. G. High-potential fields of primary consumer research in the Internet. Vestnik Sibirskogo instituta biznesa i informacionnyh tekhnologij, 2016, (3): 36-40. (In Russ.)

16. Serebriakov E. V., Pyankova L. A. Imbalance between demand and supply of labor in the Kemerovo region in 2018. Simvol nauki, 2019, (1): 125-127. (In Russ.)

17. Nanavyan A. M. Structure of population by level of education and saturate of branches of economy by personnel. Economic science of contemporary Russia, 2016, (2): 68-77. (In Russ.)

18. Kasradze T., Zarnadze N. Enhancing workforce competitiveness through improving quality of education - an indispensable means for overcoming poverty. International Journal of Innovative Technologies in Economy, 2018, 1(5): 19-21. DOI: 10.31435/rsglobal_ijite/01062018/5654 